Article

\title{
Divergent Responses of Foliar N:P Stoichiometry During Different Seasons to Nitrogen Deposition in an Old-Growth Temperate Forest, Northeast China
}

\author{
Dongxing Yang, Hongrui Mao and Guangze Jin *(D) \\ Center for Ecological Research, Northeast Forestry University, Harbin 150040, China; \\ ydx19930719@sina.com (D.Y.); damao731@126.com (H.M.) \\ * Correspondence: kwpine@nefu.edu.cn; Tel.: +86-451-82191823
}

Received: 4 February 2019; Accepted: 10 March 2019; Published: 13 March 2019

check for updates

\begin{abstract}
Atmospheric nitrogen $(\mathrm{N})$ deposition has rapidly increased during the last few decades; however, the seasonal responses of leaf N:P stoichiometry to N deposition remain unclear. In 2008, a simulated $\mathrm{N}$ deposition experiment $\left(0,30,60\right.$, and $\left.120 \mathrm{~kg} \cdot \mathrm{N} \cdot \mathrm{ha}^{-1} \cdot \mathrm{yr}^{-1}\right)$ was conducted in an old-growth temperate forest in Northeast China. In 2014, the leaves of 17 woody species and soil were sampled in spring, summer, and autumn in each treatment, and N:P stoichiometry was assessed. Community $\mathrm{N}$ and $\mathrm{P}$ in summer were significantly lower than that in spring and autumn. Unlike broadleaved species, conifers showed no significant variation among the three seasons. $\mathrm{N}$ addition significantly enhanced community $\mathrm{N}$ and soil available $\mathrm{P}$ but decreased soil total $\mathrm{P}$ in summer and autumn, and decreased community $\mathrm{P}$, as well as the P concentration of three life forms (conifer, tree, and shrub), in autumn. Our results emphasize the importance of multiple sampling across seasons in temperate forests. Arguing against the traditional consensus, the productivity of the old-growth temperate forests is limited by both $\mathrm{N}$ and $\mathrm{P}$.
\end{abstract}

Keywords: nitrogen deposition; N and P colimitation; leaf N:P stoichiometry; soil N:P stoichiometry; seasonal variations

\section{Introduction}

Increased atmospheric nitrogen $(\mathrm{N})$ deposition due to the combustion of fossil fuels and the increase in agricultural production during the last few decades, has captured the attention of many ecologists [1-3]. $\mathrm{N}$ deposition also has rapidly increased in China since the 1980s because of the country's rapid industrial development [4,5]. In addition, $\mathrm{N}$ and $\mathrm{P}$ are commonly considered the two most limiting elements of net primary productivity (NPP) in terrestrial ecosystems [6,7], increased $\mathrm{N}$ deposition may result in an imbalance in the input of $\mathrm{N}$ vs. $\mathrm{P}$ in ecosystems [8,9] and further alter foliar N:P, the community nutrient limitation, and species composition [10-12].

Although positive effects of increased foliar $\mathrm{N}$ by $\mathrm{N}$ deposition are often reported [8,13], neutral and even inhibitory effects have also been observed [14,15]. Studies of foliar P under N deposition are relatively less common than those of foliar $\mathrm{N}$ [16], and foliar $\mathrm{N}: \mathrm{P}$ ratio variations under $\mathrm{N}$ deposition remain uncertain. In fact, the determination of a limiting status is important for predicting how a change in foliar N:P stoichiometry under $\mathrm{N}$ deposition occurs. The effects of $\mathrm{N}$ deposition on community production and on N:P stoichiometry occur in three stages [16-18]. During the first stage, plant growth under $\mathrm{N}$ limitation will show a rapid increase [19]. During the second stage, the response of plant growth will decrease compared to that during the first stage as the status of $\mathrm{N}$ saturation is approached [17]. When $\mathrm{N}$ limitation changes to $\mathrm{P}$ limitation during the third stage, increased $\mathrm{N}$ input may result in the loss of soil available nutrients, and plant growth will be inhibited in response 
to $\mathrm{N}$ deposition [14]. In addition, $\mathrm{P}$ is a major limiting nutrient in tropical regions with old-aged soils, whereas temperate regions in the Northern Hemisphere with younger soils are often limited by $\mathrm{N}$ [7]. Arguing against the traditional consensus, Elser et al. [6] suggested that $\mathrm{P}$ limitation has an equivalent status to that of $\mathrm{N}$ limitation across terrestrial systems. Through a fertilization experiment in 13 boreal forests, Goswami et al. [20] found evidence that most middle-aged and mature forests exhibit $\mathrm{P}$ limitation rather than $\mathrm{N}$ limitation. Other studies have described a shift from $\mathrm{N}$ limitation to $\mathrm{P}$ limitation with succession, as $\mathrm{N}$-cycling properties recover and the dominance of a conservative $\mathrm{P}$ cycle re-emerges, in mature and old-growth forests [21,22]. Overall, as the critical forest type of the northern region of China, further research on the mixed broadleaved-Korean pine (Pinus koraiensis) forest, an old-growth temperate forest, regarding its nutrient limitation status is needed.

Initially, fertilization experiments are widely employed to assess community nutrient status and $\mathrm{N}$ or $\mathrm{P}$ limitation [23-26]. Based on the strong relationship between $\mathrm{N}$ and $\mathrm{P}$, Koerselman and Meuleman [27] also proposed a simple method that utilizes the foliar N:P ratio to evaluate the limiting status. However, a one-time sampling may not fully reflect the stoichiometric characteristics of a plant community [28]. Because of the change in foliar development stages and the existence of a retranslocation mechanism in plant leaves, foliar $\mathrm{N}$ and $\mathrm{P}$ may undergo marked variations through two seasons in just a few months, even in mature green leaves $[19,29,30]$. Thus, considering the effect of seasonal change is important when studying patterns of change in foliar N:P stoichiometry and the response of foliar N:P stoichiometry to $\mathrm{N}$ deposition. To our knowledge, there is no research focusing on the effects of $\mathrm{N}$ deposition on foliar N:P stoichiometry in different seasons.

Because plant traits affect internal and external nutrient cycling, different responses to $\mathrm{N}$ deposition and seasonal change may appear among species and plant functional groups [7,31]. Additionally, mycorrhizae, as a type of key classification for plants, are also attracting the attention of many biologists and ecologists $[20,32,33]$. Indeed, mycorrhizal symbiosis has a strong effect on plant growth and plays a key role in nutrient cycling [34,35], and various mycorrhizal types possess different mechanisms and capacities for influencing the process in which plants acquire nutrients from the soil. For example, the hyphae of mycorrhizal fungi can search for limited nutrients, including nitrates and phosphates, to support plant growth, but only ectomycorrhizal (EM) and ericoid mycorrhizal fungi can obtain organically bound nutrients [36]. As plants of old-growth temperate forests are associated with both arbuscular mycorrhizal (AM) and ectomycorrhizal (EM) species, the plants associated with differential mycorrhizal types may have diverse responses to altered surroundings.

This study investigated the effects of seasonal changes on the response pattern of leaf N:P stoichiometry to $\mathrm{N}$ deposition through a simulated $\mathrm{N}$ addition experiment. We sought to determine (1) how leaf stoichiometric characteristics change with seasonal change, (2) whether the responses of the leaf N:P stoichiometry to $\mathrm{N}$ deposition show differences in three seasons, and (3) the nature of the nutrient limitation status of an old-growth temperate forest in Northeast China.

\section{Materials and Methods}

\subsection{Site Description}

The study site is in the Heilongjiang Liangshui National Nature Reserve $\left(47^{\circ} 10^{\prime} 50^{\prime \prime} \mathrm{N}\right.$, $128^{\circ} 53^{\prime} 20^{\prime \prime}$ E) in Dailing, Heilongiiang Province, Northeast China. The annual mean temperature is $-0.3{ }^{\circ} \mathrm{C}$, and the annual mean maximum temperature is $7.5^{\circ} \mathrm{C}$. The annual mean minimum temperature is $-6.6{ }^{\circ} \mathrm{C}$. The $\geq 0{ }^{\circ} \mathrm{C}$ accumulated temperature is $2200^{\circ} \mathrm{C}-2600{ }^{\circ} \mathrm{C}$. The annual mean precipitation is $676 \mathrm{~mm}$, and $>90 \%$ of the precipitation falls during the growing season from May to October. There are 100-120 frost-free days and 130-150 snow-cover days. The average elevation is $400 \mathrm{~m}$, and the difference in the relative elevation is $100-200 \mathrm{~m}$. The zonal soil is a dark brown forest soil. The mixed broadleaved-Korean pine (Pinus koraiensis) forest is the zonal vegetation of the reserve. The stand age is between 200 and 300 years, with some individual ages older than 400 years. 


\subsection{Experimental Design and Measurements}

The $\mathrm{N}$ addition experiment began during May 2008 in the mixed broadleaved-Korean pine (Pinus koraiensis) forest, an old-growth temperate forest. Twelve $20-\mathrm{m} \times 20-\mathrm{m}$ sequential plots were established in a random manner. To prevent mutual interference, $10-\mathrm{m}$ barriers between adjacent plots were retained. In every plot, species with a diameter at breast height $(\mathrm{DBH}, 1.3 \mathrm{~m})$ $>2 \mathrm{~cm}$ were surveyed; species, DBH, and coordinates were recorded and labeled in May 2008 and surveyed again in July 2014. The background conditions of each plot surveyed in 2008 are shown in Table 1. Using urea $\left(\mathrm{CO}\left(\mathrm{NH}_{2}\right)_{2}\right)$ as the $\mathrm{N}$ source, four treatment groups were established, with three replicates-control (N0, $\left.0 \mathrm{~kg} \cdot \mathrm{ha}^{-1} \cdot \mathrm{yr}^{-1}\right)$, low $\mathrm{N}\left(\mathrm{N} 1,30 \mathrm{~kg} \cdot \mathrm{ha}^{-1} \cdot \mathrm{yr}^{-1}\right)$, medium $\mathrm{N}\left(\mathrm{N} 2,60 \mathrm{~kg} \cdot \mathrm{ha}^{-1} \cdot \mathrm{yr}^{-1}\right)$, and high $\mathrm{N}\left(\mathrm{N} 3,120 \mathrm{~kg} \cdot \mathrm{ha}^{-1} \cdot \mathrm{yr}^{-1}\right)$. The background $\mathrm{N}$ deposition (inorganic and organic $\mathrm{N}$ ) was $12.9 \mathrm{~kg} \cdot \mathrm{N} \cdot \mathrm{ha}^{-1} \cdot \mathrm{yr}^{-1}$, as recorded by a dry-wet deposition collector (New Star Environmental LLC, Roswell, GA, USA). N additions were applied at the beginning of June, July, and August every year and began in June 2008. The $\mathrm{CO}\left(\mathrm{NH}_{2}\right)_{2}$ for each treatment was dissolved in $20 \mathrm{~L}$ of water, and the solutions were sprayed onto the soil surface using a backpack sprayer. The control group was sprayed with the same amount of water.

Table 1. Natural conditions in each plot before the $\mathrm{N}$ addition experiment in 2008.

\begin{tabular}{|c|c|c|c|c|c|c|c|}
\hline Plots & Treatments & $\begin{array}{c}\text { Average N Addition } \\
\left(\mathrm{kg} \cdot \mathrm{ha}^{-1} \cdot \mathrm{yr}^{-1}\right)\end{array}$ & Repeat & $\begin{array}{c}\text { Density } \\
\left(\text { trees }^{\prime} \mathbf{h a}^{-1}\right)\end{array}$ & $\begin{array}{c}\text { Mean Breast } \\
\text { Diameter }(\mathrm{cm})\end{array}$ & $\begin{array}{l}\text { Slope } \\
\text { Aspect }\end{array}$ & $\begin{array}{l}\text { Slope } \\
\text { Degree }\end{array}$ \\
\hline 1 & No & 0 & N0-1 & 1325 & 10.70 & $\mathrm{~W}$ & $<6^{\circ}$ \\
\hline 3 & N1 & 30 & N1-1 & 1575 & 8.46 & W & $<6^{\circ}$ \\
\hline 4 & N3 & 120 & N3-1 & 2925 & 7.68 & W & $<6^{\circ}$ \\
\hline 7 & N0 & 0 & N0-3 & 1650 & 9.43 & W & $<6^{\circ}$ \\
\hline 8 & N1 & 30 & N1-2 & 1550 & 11.47 & W & $<6^{\circ}$ \\
\hline 9 & N1 & 30 & N1-3 & 1575 & 10.41 & W & $<6^{\circ}$ \\
\hline 10 & $\mathrm{~N} 2$ & 60 & N2-1 & 2300 & 7.62 & W & $<6^{\circ}$ \\
\hline 11 & N2 & 60 & N2-2 & 1800 & 11.44 & W & $<6^{\circ}$ \\
\hline
\end{tabular}

When collecting samples from tall trees, a branch with many leaves and sufficient sunlight was cut by a person specialized in climbing trees. The healthy and green leaves were selected and placed into a plastic vacuum packaging bag. Seventeen species were collected randomly in 3 plots for each treatment in the middle of May, July, and September during 2014. However, insufficient material was collected for a proportion of the species because of natural and anthropogenic reasons; for example, most of the Fraxinus mandshurica individuals had not renewed their foliage in May, and their leaves had already fallen by September, or a few trees were so high that samples could not be obtained. In this study, May, July, and September represented spring, summer, and autumn, respectively. The 17 species were of three types - deciduous broad-leaved trees, deciduous broad-leaved shrubs and evergreen conifers (hereafter trees, shrubs and conifers, respectively). Conifers were assigned their own group because they have unique traits compared to those of other trees [7]. The mycorrhizal types of species in this study were according to Shi et al. [37], and species belonging to the same family were classified into the same mycorrhizal type. The detailed sampling information is listed in Table 2.

Soil samples were also collected at the same time as leaf samples. In each plot, soils were randomly sampled by taking three $5-\mathrm{cm}$-diameter soil cores from depths of $0-10,10-20,20-30$, and $30-40 \mathrm{~cm}$. The litter on the soil surface was removed before sampling. The samples were placed in plastic bags and transported to the lab after being air-dried. 
Table 2. Sampling condition of each species in 2014.

\begin{tabular}{|c|c|c|c|c|c|c|}
\hline \multirow{2}{*}{ Scientific Name of Species } & \multirow{2}{*}{ Life Form } & \multirow{2}{*}{$\begin{array}{l}\text { Ectomycorrhizal (EM) or } \\
\text { Arbuscular Mycorrhizal (AM) }\end{array}$} & \multirow{2}{*}{$\begin{array}{l}\text { The important value (\%) } \\
\text { under Control Group in } 2014\end{array}$} & \multicolumn{3}{|c|}{ Uncollected Samples in Different Treatments } \\
\hline & & & & Spring & Summer & Autumn \\
\hline Pinus koraiensis & Conifer & EM & 27.67 & N3 & & \\
\hline Acer mono & Tree & EM & 11.19 & & N1 & \\
\hline Corylus mandshurica & Shrub & EM & 9.60 & & & \\
\hline Tilia amurensis & Tree & EM & 8.04 & N1 & & N1 \\
\hline Betula costata & Tree & EM & 7.05 & N1 N2 N3 & & N0 N1 N2 \\
\hline Ulmus laciniata & Tree & EM & 5.66 & & & \\
\hline Ulmus japonica & Tree & EM & 4.13 & N2 & & \\
\hline Acer tegmentosum & Tree & $\mathrm{AM}$ & 3.75 & & N1 & N0 N1 N2 N3 \\
\hline Fraxinus mandshurica & Tree & $\mathrm{AM}$ & 3.03 & N1 N2 N3 & & N1 N2 \\
\hline Prunus padus & Tree & $\mathrm{AM}$ & 1.98 & & & \\
\hline Syringa reticulate var. mandshurica & Tree & $\mathrm{AM}$ & 1.54 & & & \\
\hline Acer ukurunduense & Tree & EM & 1.19 & N1 & N1 & \\
\hline Euonymus pauciflorus & Shrub & $\mathrm{AM}$ & 1.13 & & & \\
\hline Picea koraiensis & Conifer & EM & 0 & N2 & & \\
\hline Deutzia gladata & Shrub & $\mathrm{AM}$ & 0 & & & \\
\hline Lonicera chrysantha & Shrub & $\mathrm{AM}$ & 0 & & & \\
\hline Ribes mandschuricum & Shrub & $\mathrm{AM}$ & 0 & & & \\
\hline
\end{tabular}


Each leaf sample was ground to a fine powder, passed through a $0.149-\mathrm{mm}$ mesh, and enveloped. The sample was oven-dried at $65^{\circ} \mathrm{C}$ to a constant weight for further analysis. The soil sample was passed through a 2-mm mesh; a portion was conserved in an envelope, and the remaining material was conserved after passing through a 0.149-mm mesh. In October 2014, leaf $\mathrm{N}$ concentration was analyzed using a Kjeltec KTM 2300 analyzer (Foss Teactor $\mathrm{AB}$, Hoganas, Sweden) after $\mathrm{H}_{2} \mathrm{SO}_{4}+\mathrm{K}_{2} \mathrm{SO}_{4}+\mathrm{CuSO}_{4}$ digestion. Soil total $\mathrm{N}(\mathrm{TN})$ in every layer was analyzed using the same method but with $\mathrm{H}_{2} \mathrm{SO}_{4}+\mathrm{H}_{2} \mathrm{O}_{2}$ digestion. Leaf and soil total $\mathrm{P}$ (TP) were measured using the molybdenum antimony colorimetric spectrophotometer method after $\mathrm{H}_{2} \mathrm{SO}_{4}+\mathrm{H}_{2} \mathrm{O}_{2}$ digestion. These samples were oven-dried again at $65^{\circ} \mathrm{C}$ for $2 \mathrm{~h}$ before digestion. For soil available P (AP), 2-mm of soil from every layer was pooled and fully mixed, and the air-dried soil was extracted using $0.05 \mathrm{~mol} \cdot \mathrm{L}^{-1} \mathrm{HCl}+0.025 \mathrm{~mol} \cdot \mathrm{L}^{-1} \mathrm{H}_{2} \mathrm{SO}_{4}$. The $\mathrm{P}$ concentration in the extract was measured using the molybdenum antimony colorimetric spectrophotometer method. $\mathrm{N}$ and $\mathrm{P}$ concentrations are expressed as $\mathrm{mg} \cdot \mathrm{g}^{-1}$, and a mass basis was used to calculate stoichiometric ratios.

\subsection{Statistical Analyses}

The important value (IV) of $i$-th species in each treatment group in 2008 and 2014 were calculated using the following equation:

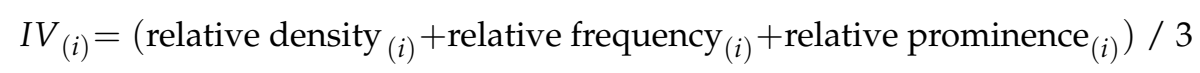

The change in $I V s$ for each species was directly calculated using the following equation:

$$
\text { The changed } \text { value }_{(i)}=I V_{(i)(2014)}-I V_{(i)(2008)}
$$

Two-way analysis of variance (ANOVA) with season and treatment as fixed factors was applied to examine the effects on leaf and soil N, $\mathrm{P}$ and the N:P ratio based on averages. Community N:P stoichiometry ( $\mathrm{N}: \mathrm{P}$ stoichiometry means $\mathrm{N}, \mathrm{P}$, and the N:P ratio, community N:P stoichiometry means $\mathrm{N}: \mathrm{P}$ stoichiometry of the plant community) weighted by $I V_{(i)(2014)}$ was also examined in the same manner (hereafter, community N:P stoichiometry is the leaf N:P stoichiometry weighted by the $\left.I V_{(i)(2014)}\right)$. Meanwhile, the marginal means of the main factors were calculated and recorded. Three-way ANOVA with season, treatment, and different groups (broadleaves vs. conifers, trees vs. shrubs, ectomycorrhizal species (EM) vs. arbuscular mycorrhizal species (AM), broadleaves including broadleaved trees and shrubs; the data for conifers were not included in tree and EM groups) as fixed factors were used to analyze effects on leaf $\mathrm{N}, \mathrm{P}$, and the N:P ratio. Nonsignificant interactions were removed from the analysis. Leaf $\mathrm{P}$, the leaf $\mathrm{N}: \mathrm{P}$ ratio and soil N:P stoichiometry in our data were apparently of right-skewed distribution, and they were naturally logarithmically transformed before performing ANOVA; untransformed data are shown in the figures.

The data were separated according to (1) different seasons and (2) different seasons and different classified groups. Least squares discrimination (LSD) one-way ANOVA was applied to assess differences between treatment groups, and $I V_{(i)}(2014)$ was calculated as weightiness. Differences between N:P stoichiometry averages in our study and previous studies were evaluated using the one-sample $t$-test. The Kolmogorov-Smirnov and Levene's tests were employed to assess the normality of the residuals and the homogeneity of variance, respectively. All figures were created using Origin 9.0, and all data were analyzed using SPSS 20 (SPSS, Inc., Chicago, IL, USA). Significance was determined at the 0.05 level.

\section{Results}

\subsection{N, P, and the N:P Ratio in the Three Seasons Under Ambient (without N Addition) Conditions}

Community $\mathrm{N}$, average $\mathrm{N}$, and soil $\mathrm{N}$ showed a significant increase in September after an initial decrease from spring to summer (Figure 1a,d and Figure 2a). A significant increase from spring 
to autumn was found for soil $\mathrm{N}: \mathrm{P}$, which exhibited the same trend as soil $\mathrm{N}$ and average $\mathrm{N}: \mathrm{P}$ (Figures $1 \mathrm{f}$ and $2 \mathrm{a}, \mathrm{d}$ ). Community N:P in autumn was significantly lower than that in summer but was significantly higher than that in spring. Community $\mathrm{P}$ and average $\mathrm{P}$ in spring were significantly higher than those in the other two seasons (Figure 1b,c,e,f). Although soil TP showed no significant variation during the three seasons, soil AP had a similar trend to that of community $\mathrm{P}$, tending to increase again in autumn after a significant decrease in summer (Figures $1 b$ and $2 b, c$ ). The leaf N:P stoichiometry of conifers was significantly lower than that of trees and shrubs $(p<0.05)$, and the conifer P and N:P ratios displayed no significant seasonal variation, different from the patterns of the trees and shrubs. Moreover, a nearly identical seasonal pattern between the trees and shrub N:P stoichiometry was observed (Figure 3a-i).
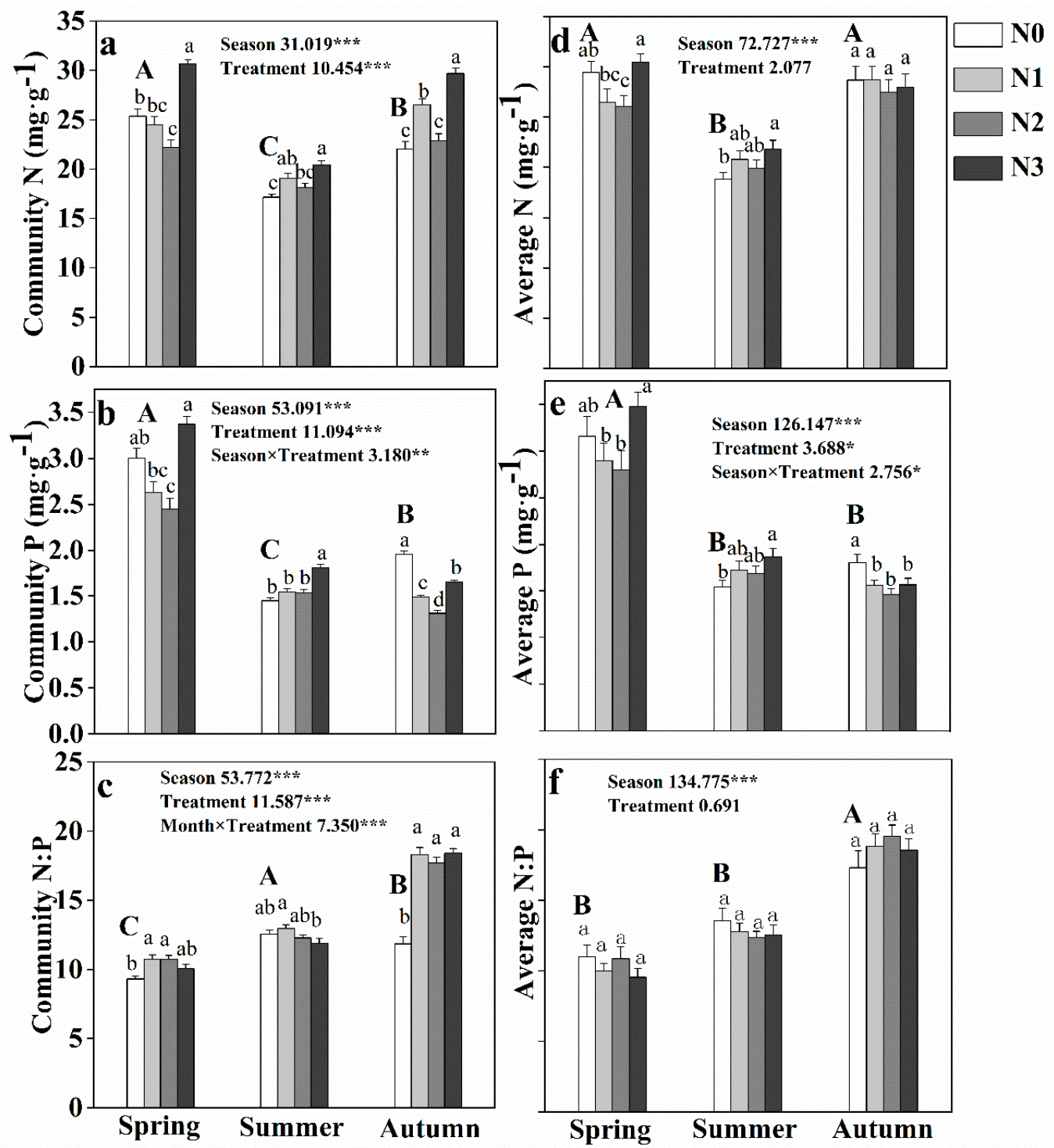

Figure 1. Effects of $\mathrm{N}$ addition on community and average $\mathrm{N}(\mathbf{a}, \mathbf{d}), \mathrm{P}(\mathbf{b}, \mathbf{e})$ and the N:P ratio $(\mathbf{c}, \mathbf{f})$ in three seasons. The results of two-way ANOVAs are shown in each panel and interactions without significance were removed from the analysis. The results of least squares discrimination (LSD) one-way ANOVA were shown above the bars. Different uppercase letters indicate a significant difference among the three seasons under ambient conditions. Different lowercase letters indicate a significant difference among treatments in each month. Data are shown as the mean $+S E .{ }^{*} p<0.05,{ }^{* *} p<0.01,{ }^{* * *} p<0.001$. 

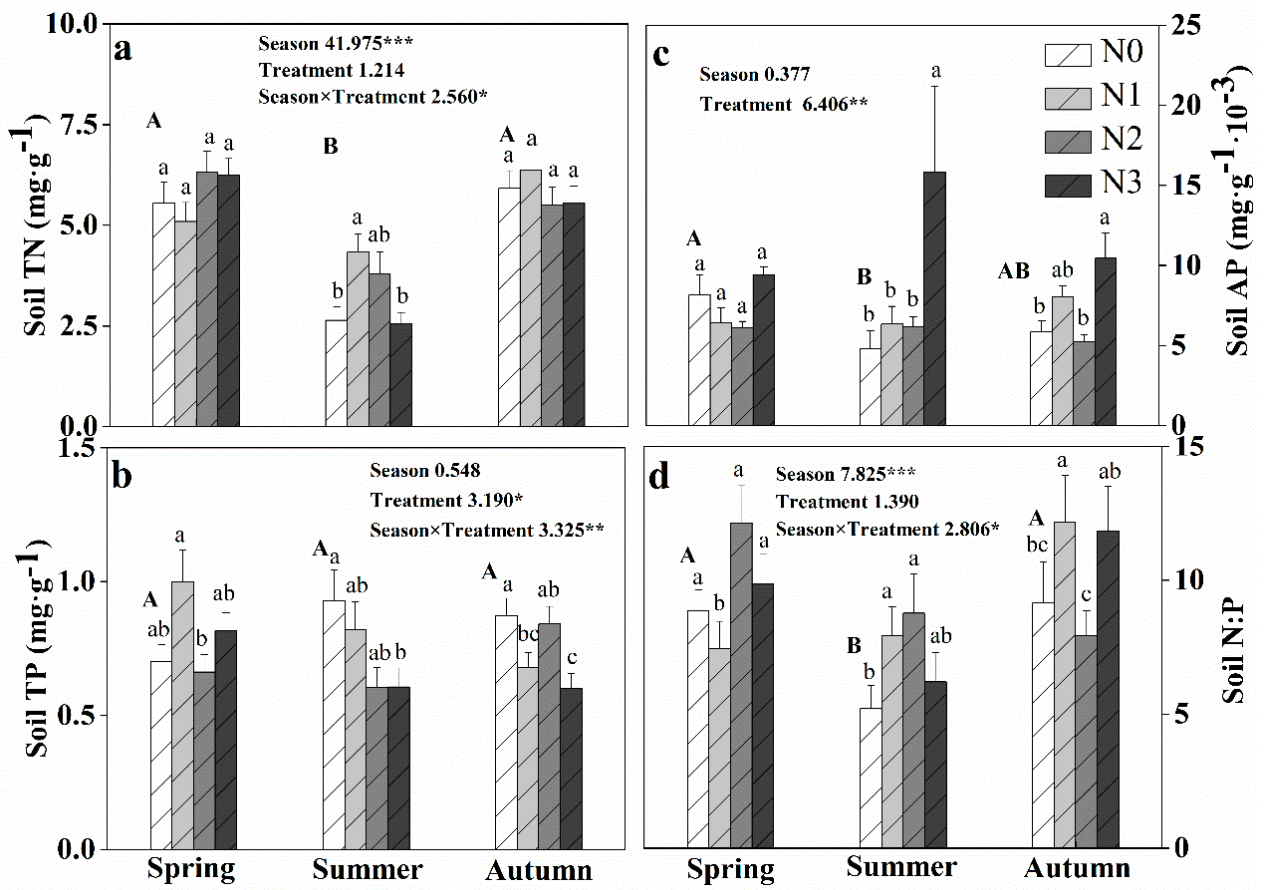

Figure 2. Effects of $\mathrm{N}$ addition on soil total $\mathrm{N}(\mathrm{TN})(\mathbf{a})$, soil total $\mathrm{P}(\mathrm{TP})(\mathbf{b})$, soil available $\mathrm{P}(\mathrm{AP})$ (c) and soil total N:P ratio (d) in the three seasons. The results of two-way ANOVAs are shown in each panel and interactions without significance were removed from the analysis. The results of least squares discrimination (LSD) one-way ANOVA were shown above the bars. Different uppercase letters indicate a significant difference among the three seasons under ambient conditions. Different lowercase letters indicate a significant difference among the treatments in each month. Data are shown as the mean $+S E$. ${ }^{*} p<0.05,{ }^{* *} p<0.01,{ }^{* * *} p<0.001$.

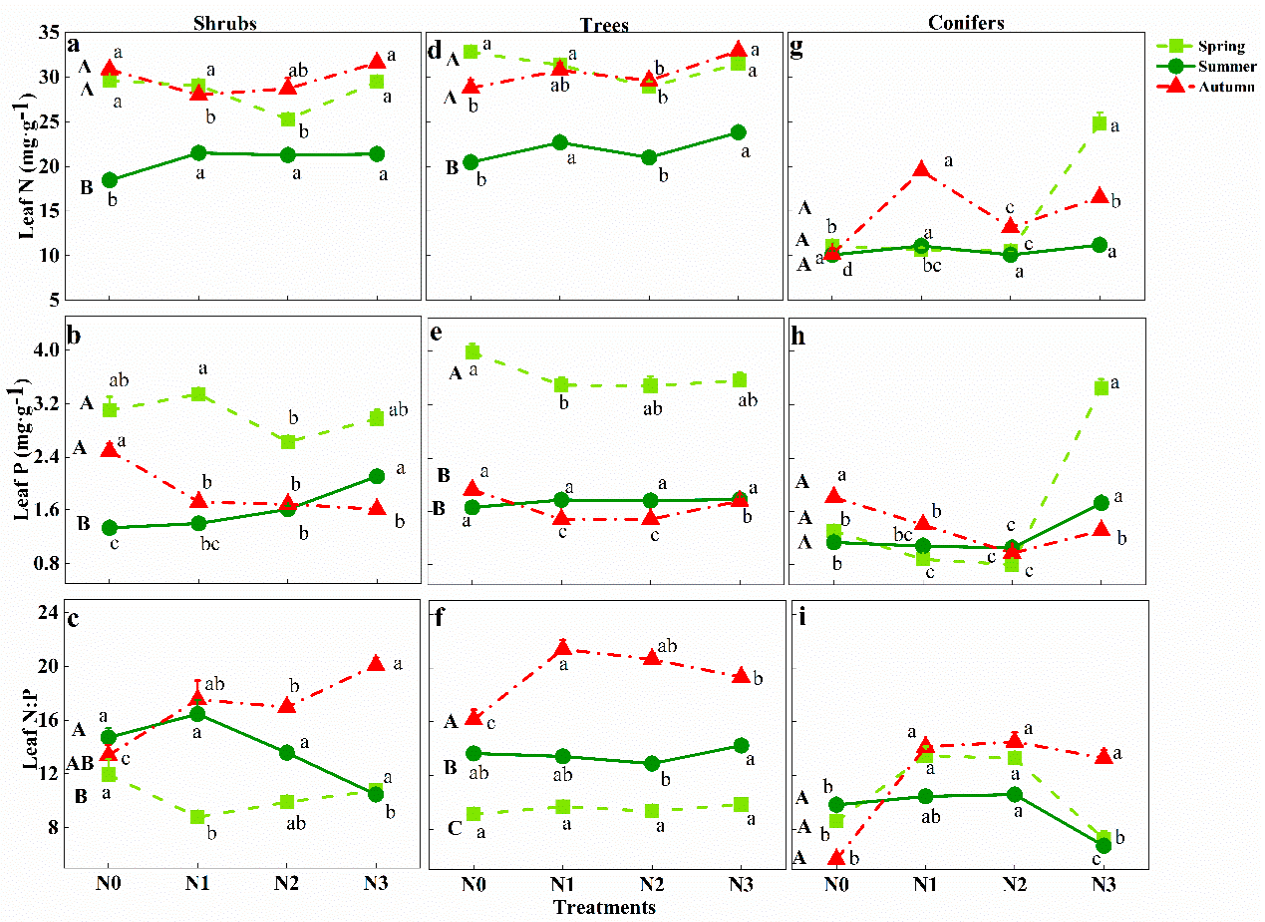

Figure 3. Effects of $\mathrm{N}$ addition on leaf $\mathrm{N}(\mathbf{a}, \mathbf{d}, \mathbf{g})$, leaf $\mathrm{P}(\mathbf{b}, \mathbf{e}, \mathbf{h})$ and the leaf $\mathrm{N}: \mathrm{P}$ ratio $(\mathbf{c}, \mathbf{f}, \mathbf{i})$ of three life forms in three seasons. Different uppercase letters indicate a significant difference among the three seasons under ambient. Different lowercase letters indicate a significant difference among the treatments in each month. Data are shown as the mean $+S E$. 
Summer was the peak season in the survey region. During this season, leaf average $\mathrm{N}$ and $\mathrm{P}$ in our study was similar to the average for plants in China, though N:P was significantly lower. Leaf P was significantly lower than reported in two global studies, and leaf $\mathrm{N}$ was significantly lower than that in the study of Elser et al. [38]. We also found some inconsistent results for leaf N:P stoichiometry in spring and autumn compared to that in summer (Table 3).

Table 3. Comparison of the average leaf N, P, and N:P in our study with China and the world.

\begin{tabular}{|c|c|c|c|c|c|c|c|c|c|}
\hline \multirow{2}{*}{$\begin{array}{c}\text { Stoichiometry } \\
\text { and Seasons }\end{array}$} & \multicolumn{3}{|c|}{$\mathbf{N}$} & \multicolumn{3}{|c|}{$\mathbf{P}$} & \multicolumn{3}{|c|}{$\mathrm{N}: \mathrm{P}$} \\
\hline & Spring & Summer & Autumn & Spring & Summer & Autumn & Spring & Summer & Autumn \\
\hline Han et al. [39] & & 20.2 & & & 1.46 & & & 16.3 & \\
\hline (China) & $+^{*}$ & - & $+^{*}$ & $+^{*}$ & + & $+*$ & $-{ }^{*}$ & $-{ }^{*}$ & + \\
\hline $\begin{array}{l}\text { Reich and Oleksyn } \\
\text { [7] }\end{array}$ & & 20.1 & & & 1.77 & & & 13.8 & \\
\hline (World) & $+^{*}$ & - & $+^{*}$ & $+^{*}$ & $-{ }^{*}$ & + & $-{ }^{*}$ & - & $+^{*}$ \\
\hline Elser et al. [38] & & 20.6 & & & 1.99 & & & 12.7 & \\
\hline (World) & $+^{*}$ & $-*$ & $+*$ & $+*$ & $-{ }^{*}$ & - & - & + & $+^{*}$ \\
\hline
\end{tabular}

" + " means the average in this study is higher than average of China and the world. " $-"$ means the value in this study is lower than the tested value. ${ }^{*} p<0.05$.

\subsection{Effect of N Addition on Community and Soil N:P Stoichiometry during Different Seasons}

Community $\mathrm{N}$ and $\mathrm{P}$ showed a similar variation to that of average $\mathrm{N}$ and $\mathrm{P}$ under $\mathrm{N}$ addition in spring and summer, with a similar change pattern for $\mathrm{N}$ to that of $\mathrm{P}$ (Figure 1a,b,d,e). During spring, community $\mathrm{N}$ and average $\mathrm{N}$ were significantly increased under $\mathrm{N} 3$ after a decreasing trend (Figure 1a,d). Significant increases in community N:P were found for N1 and N2 treatments, but there was no significant variation between the different treatment groups with regard to average $\mathrm{N}: \mathrm{P}$ (Figure $1 \mathrm{c}, \mathrm{f})$. In summer, an upward trend in community and average $\mathrm{N}$ and $\mathrm{P}$ was observed (Figure 1a,b,d,e); community N:P under N3 was significantly lower than that under N1, and there was no significant effect of $\mathrm{N}$ deposition on average $\mathrm{N}: \mathrm{P}$ (Figure 1c,f). In autumn, $\mathrm{N}$ addition significantly increased community $\mathrm{N}, \mathrm{P}$, and $\mathrm{N}: \mathrm{P}$ and significantly decreased average $\mathrm{P}$; however, there was no significant variation in average $\mathrm{N}$ and N:P (Figure 1a-f). A two-way ANOVA showed that seasonal change had a significant impact on the community and average N:P stoichiometry (Figure 1a-f). Treatment also had a significant impact on community N:P stoichiometry but no significant impact on average $\mathrm{N}$ and $\mathrm{N}: \mathrm{P}$ (Figure 1c,d,f). In addition, their interaction had a significant influence on community $\mathrm{P}, \mathrm{N}: \mathrm{P}$ and average $\mathrm{P}$ (Figure $1 \mathrm{~b}, \mathrm{c}, \mathrm{e})$.

During summer, soil $\mathrm{N}$ and $\mathrm{N}: \mathrm{P}$ showed an increasing trend, with a decrease under N3. In addition, the N3 treatment significantly decreased soil $\mathrm{P}$ and increased soil AP. The patterns of variation in soil $\mathrm{P}$ and soil AP in autumn were similar to those in summer; soil N:P increased under $\mathrm{N} 1$ and N3, and soil N showed no significant change (Figure 2a-d). A two-way ANOVA showed that seasonal change had a significant impact on soil $\mathrm{N}$ and soil $\mathrm{N}: \mathrm{P}$, and treatment had a significant impact on soil P and soil AP; however, their interaction had no significant impact on soil AP (Figure 2a-d). In addition, the marginal means of main factors (season and treatment) are listed in the Table S1.

\subsection{Response of Leaf N:P Stoichiometry in Different Groups to Seasonal Change and N Addition}

A three-way ANOVA showed that although only a small variation in the response of N:P stoichiometry between shrubs and trees to $\mathrm{N}$ addition was found in the three seasons, the response was significantly different than that of conifers (Table 4; Figure 3a-i). In spring, the leaf $\mathrm{N}$ of shrubs, trees and conifers all exhibited a significant decrease under $\mathrm{N} 2$ that was increased under N3 (Figure 3a,d,g). A similar decrease under N2 in leaf $\mathrm{P}$ was found (Figure 3b,e,h). In summer, $\mathrm{N}$ addition significantly increased $\mathrm{N}$ in trees and shrubs, with no remarkable effect on conifer $\mathrm{N}$ (Figure $3 a, d, g$ ). In autumn, increased leaf $\mathrm{N}$ was found in the leaves of the trees and conifers, but their 
leaf $\mathrm{P}$ showed a trend opposite to leaf $\mathrm{N}$ under $\mathrm{N}$ addition (Figure $3 \mathrm{~d}, \mathrm{e}, \mathrm{g}, \mathrm{h}$ ). $\mathrm{N}$ addition significantly increased the N:P of shrub, trees, and conifers in autumn (Figure 3c,f,i).

A three-way ANOVA showed that different mycorrhizal types displayed notable differences in leaf N:P stoichiometry, and there were significant interactions between mycorrhizal type and other factors (Table 4; Figure 4a-f). In particular, EM species in autumn showed a nearly opposite trend to that of AM species in terms of N:P stoichiometry (Figure 4a-f). From 2008 to 2014, the changed IV of AM species showed an increasing trend with higher available N. In contrast, the changed $I V$ of EM showed a decreased trend under increasing $\mathrm{N}$ addition (Figure 5).

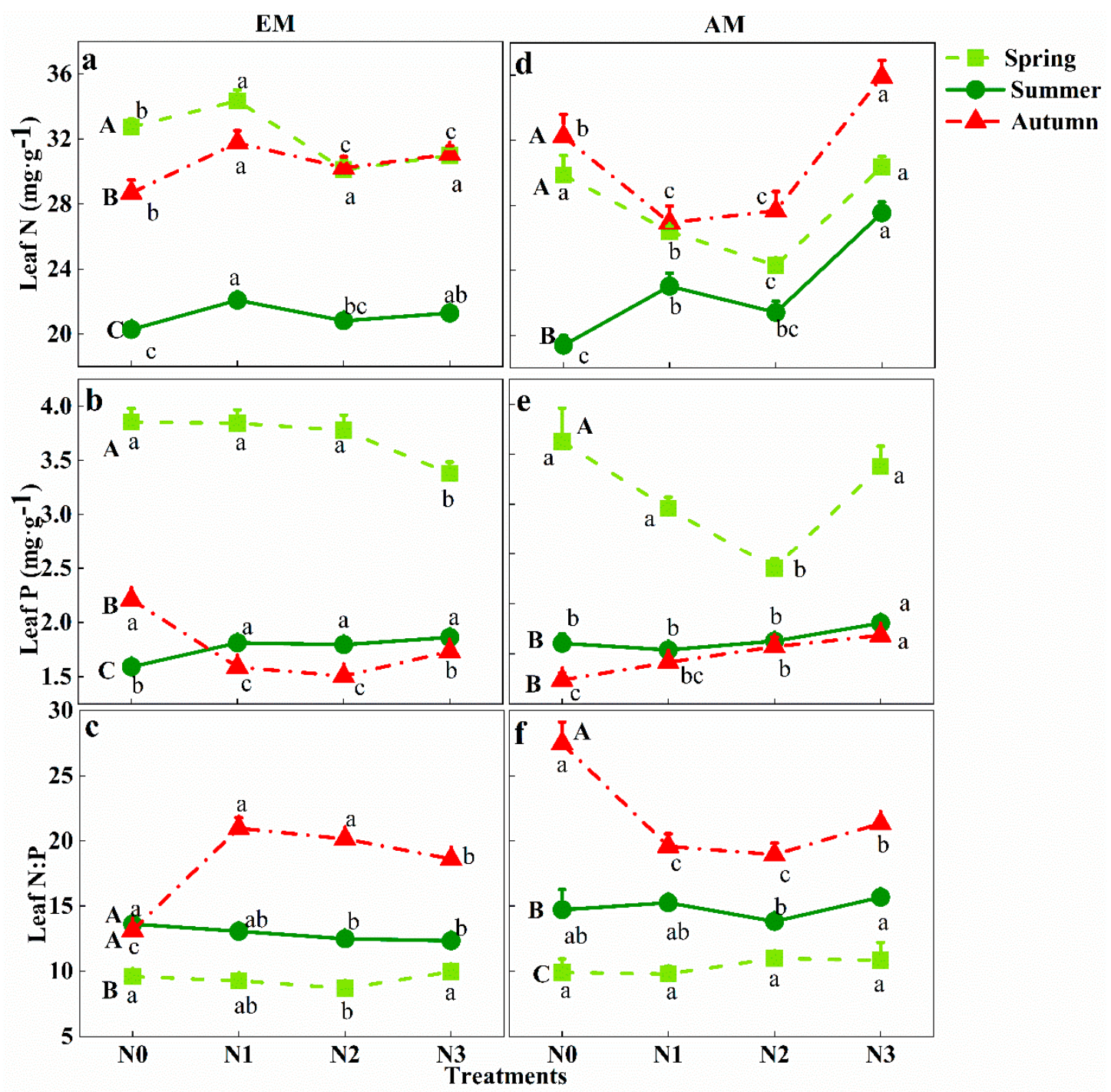

Figure 4. Effect of $\mathrm{N}$ addition on leaf $\mathrm{N}(\mathbf{a}, \mathbf{d})$, leaf $\mathrm{P}(\mathbf{b}, \mathbf{e})$ and the leaf $\mathrm{N}: \mathrm{P}$ ratio $(\mathbf{c}, \mathbf{f})$ of ectomycorrhizal species (EM) vs. arbuscular mycorrhizal species (AM) in the three seasons. Different uppercase letters indicate a significant difference among the three seasons under ambient conditions. Different lowercase letters indicate a significant difference among the treatments in each month. Data are shown as the mean $+S E$. 
Table 4. Results ( $F$ values) of three-way ANOVA on the effects of leaf N:P stoichiometry in different groups.

\begin{tabular}{|c|c|c|c|c|c|c|c|c|}
\hline $\begin{array}{l}\text { Different } \\
\text { Groups }\end{array}$ & Factors & Season & Treatment & Group & $\begin{array}{l}\text { Season } \times \\
\text { Treatment }\end{array}$ & $\begin{array}{l}\text { Season } \times \\
\text { Group }\end{array}$ & $\begin{array}{l}\text { Treatment } \\
\times \text { Group }\end{array}$ & $\begin{array}{c}\text { Season } \times \text { Treatment } \\
\times \text { Group }\end{array}$ \\
\hline \multirow{2}{*}{$\begin{array}{l}\text { Broadleaves } \\
\text { vs. conifers }\end{array}$} & $\mathrm{N}$ & $53.480 * * *$ & $6.269 * * *$ & $408.073^{* * *}$ & $2.857^{*}$ & $8.434^{* * *}$ & & $2.220 *$ \\
\hline & $\mathrm{P}$ & $25.034^{* * *}$ & $20.112 * * *$ & $134.599 * * *$ & $6.762 * * *$ & $18.939^{* * *}$ & $9.209^{* * *}$ & $3.286^{* *}$ \\
\hline \multirow{2}{*}{$\begin{array}{l}\text { Trees vs. } \\
\text { Shrubs }\end{array}$} & $\mathrm{N}$ & $106.743^{* * *}$ & $4.307^{* *}$ & $5.477 *$ & & & & \\
\hline & $\mathrm{P}$ & $104.666^{* * *}$ & 2.415 & 0.906 & $2.458 *$ & 3.691 * & & \\
\hline \multirow[t]{2}{*}{ EM vs. AM } & $\mathrm{P}$ & $142.893^{* * *}$ & 1.639 & $17.898^{* * *}$ & & & & $2.250 * *$ \\
\hline & $\mathrm{N}: \mathrm{P}$ & $127.291^{* * *}$ & 0.433 & $14.060^{* * *}$ & & & & $2.798^{* * *}$ \\
\hline
\end{tabular}

Interactions without significance were removed from the analysis, and the date are not shown in the table. ${ }^{*} p<0.05$, ** $p<0.01,{ }^{* * *} p<0.001$.

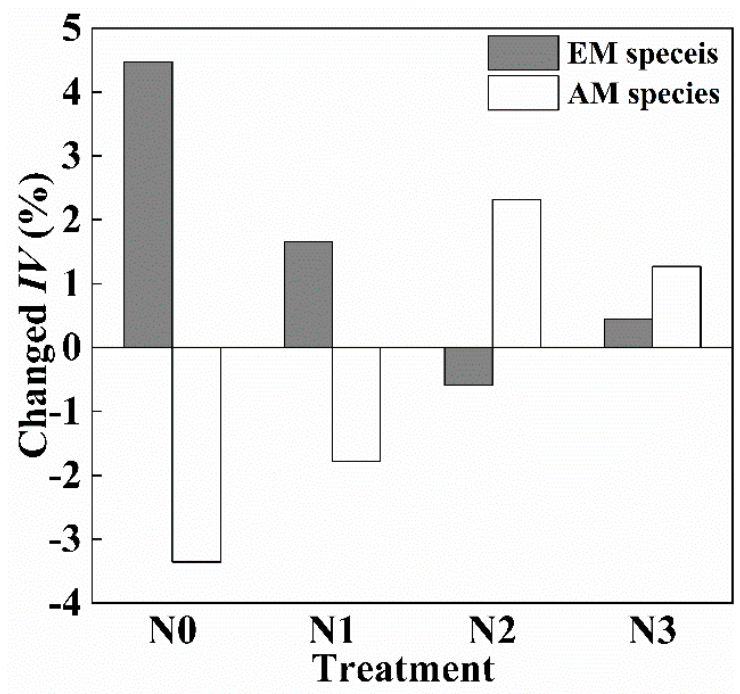

Figure 5. Changed IV (\%) of AM species and EM species from 2008 to 2014 under four treatments.

\section{Discussion}

\subsection{Seasonal Change in Leaf N:P Stoichiometry}

Consistent with previous study [19], among the three seasons, community $\mathrm{N}$ and $\mathrm{P}$ were highest in spring, which is due to the rapid growth rate of leaves [28,29]. $\mathrm{N}$ is the main element of proteins, and $\mathrm{P}$ is the main element of P-rich ribosomal RNA (rRNA). In spring, leaves are in the early stage of their growth period, the foliar size is relatively small, and foliar cells show a high degree of splitting and selection to absorb considerable $\mathrm{N}$ and $\mathrm{P}$ to support their rapid growth. Therefore, foliar nutrient concentrations are relatively high $[18,40]$. Summer is the peak season: The rate of foliar nutrient absorption is lower than that of growth, leaves are larger than they are in spring, and most of the broad leaves have fully expanded. Thus, the concentrations of nutrients are diluted, which results in rapidly decreasing nutrient concentrations in summer [41]. However, when leaves are no longer growing and are fully expanded, the dilution process stops, and foliar nutrient concentrations increase again because of continuous nutrient absorption; accordingly, community $\mathrm{N}$ and $\mathrm{P}$ in autumn are higher than in summer.

Because of the rapid decrease in foliar $\mathrm{P}$ compared to foliar $\mathrm{N}$ in summer, community $\mathrm{N}: \mathrm{P}$ is of a significantly higher level than that in spring. The sharp decrease in foliar $\mathrm{P}$ from the early growing season to the late growing season has also been found in previous studies, but without explanation $[19,42]$. A possible reason is the decreased demand for P. Because plants are older in summer than in spring, active meristems (e.g., inflorescences, shoot tips, young leaves) will restrict 
plant growth; in contrast, mature leaves no longer grow but are still photosynthetically active, which results in a greater decrease in the $P$ requirement for rRNA synthesis compared to the decrease in $\mathrm{N}$ for protein synthesis [43]. Similarly, soil AP significantly decreases, by $41.2 \%$, from spring to summer, and the percentage of soil AP of soil TP during Spring, Summer, and Autumn is $1.17 \%, 0.52 \%$, and $0.67 \%$, respectively. Wang and Moore [30] also found a strong increase in available $\mathrm{N}$ and $\mathrm{K}$ but no change in soil AP in summer and autumn compared to available $\mathrm{N}, \mathrm{P}$, and $\mathrm{K}$ in spring.

When we divided the foliar data into shrubs, trees, and conifers, remarkably different seasonal patterns and nutrient concentrations between coniferous and broadleaved species were found. Indeed, leaves with high nutrient concentrations (both $\mathrm{N}$ and $\mathrm{P}$ ) tend to be shorter lived and have a high photosynthetic capacity, whereas leaves with low nutrient concentrations tend to have longer lifespans and lower metabolic capacities [44,45] (Evergreen-Deciduous hypothesis). Conifers (mainly consisting of Pinus koraiensis, the $I V$ of which under ambient conditions is $27.67 \%$ ) maintain a low leaf nutrient status that may constitute a strategy related to canopy dominance and space occupancy [46]. In addition, unlike broadleaved species that translocate $\mathrm{N}$ and $\mathrm{P}$ to leaves during the early growing season, conifers gradually translocate these nutrients to new leaves throughout the growing season to maintain a relatively stable nutrient concentration and stoichiometry, thereby decreasing the effect of the external environment [29]. This finding confirms our results that conifers exhibit less seasonal variation than the other two plant groups examined in this study. It was also noted that the weighted $\mathrm{N}: \mathrm{P}$ stoichiometry of shrubs and trees demonstrated a pattern similar to that of the average N:P stoichiometry, although this was not the case for conifers, which explains the reduced variation in community N:P stoichiometry from summer to autumn compared to the variation in the average N:P stoichiometry. These findings suggest that compared to average values, weighted values may better reflect the N:P stoichiometry at a community level.

Similar seasonal pattern of foliar nutrient concentrations has also been exhibited in the previous study [30]: foliar $\mathrm{N}$ concentration of deciduous species showed an increased trend from July to September after a sharp decrease from May to June, though the increase was not statistically significant and there was a sharp decrease again in October due to nutrient resorption. As mentioned earlier, the seasonal pattern of $\mathrm{N}$ concentration exhibits the strong effects of foliar development stage on nutrient concentrations of leaves, and exposes the limitation of calculating foliar nutrients based on the mass ratio. In fact, it is a well-known phenomenon in agriculture that nutrient concentrations decrease with ontogenetic development of individual plants, and this decrease is mainly because of the imbalanced rate between increased nutrients and accumulated dry matter [19]. However, the application of mass ratio is still widely accepted in the field of plant stoichiometry $[16,19,43]$, because we are accustomed to thinking about organism body mass or estimating total biomass of species or components in ecosystems [40]. Nonetheless, our study suggests that compared to the foliar concentration $\left(\mathrm{mg} \cdot \mathrm{g}^{-1}\right)$, the calculation based on the foliar mass (mass·leaf ${ }^{-1}$ ) may be a better expression when considered the seasonal effects, because it can directly express the nutrient contents in leaves and ignore the effects of foliar development stage [29].

\subsection{Seasonal Variation in the Leaf N:P Stoichiometry Response to N Addition}

Seasonal change had a highly significant effect on community N:P stoichiometry. Furthermore, leaf nutrients responded differently to $\mathrm{N}$ addition in the three seasons. In fact, although $\mathrm{N}$ addition increases the availability of $\mathrm{N}$ and promotes its absorption, it can at the same time stimulate the growth of plants, which is accompanied by dilution of nutrient concentrations $[19,28]$. Thus, the differences among treatments may reflect the relative magnitude of the foliar growth rate and the nutrient absorption rate. During the early growth stage, $\mathrm{N}$ addition increases the growth rate of leaves more rapidly than it increased $\mathrm{N}$ absorption rate. Accumulated $\mathrm{N}$ is diluted by rapidly growing leaves, which results in a decreasing trend under low and medium $\mathrm{N}$ addition. When the increase in absorption rate is faster than the increase in growth rate, the $\mathrm{N}$ concentration shows an increasing trend, for example: the community $\mathrm{N}$ under high $\mathrm{N}$ addition during spring. Uniformly, the foliar 
growth rate gradually slowed or even stopped, but the effect of $\mathrm{N}$ addition on the nutrient absorption rate was still effective, which resulted in the increasing trend under $\mathrm{N}$ addition during summer.

Studies have suggested that imbalanced N-P loading affects $\mathrm{P}$ cycling and may enhance $P$ limitation $[12,45,46]$. This effect is exhibited in the decreased soil TP in summer and autumn and increased community N:P in autumn under $\mathrm{N}$ addition. In the short term, $\mathrm{N}$-induced $\mathrm{P}$ limitation may be alleviated by enhanced $\mathrm{P}$ absorption due to enhanced activity of soil and root phosphatases or by increased $\mathrm{P}$ conservation due to increased $\mathrm{P}$ resorption [47-51]. In this study, a similar change pattern between community $\mathrm{P}$ and community $\mathrm{N}$ during spring and summer was found, and soil $\mathrm{AP}$ rose significantly as a result of high $\mathrm{N}$ addition, confirming the alleviation of $\mathrm{N}$-induced $\mathrm{P}$ limitation. Mitigation of $\mathrm{N}$-induced $\mathrm{P}$ limitation under $\mathrm{N}$ deposition has also been reported in temperate plantations by Deng et al. [16] and in a semiarid grassland by Long et al. [52], reflecting the capacity of plants to regulate $\mathrm{P}$ acquired to maintain homeostasis $(H)[43,53]$.

Nonetheless, community $\mathrm{P}$ as well as the P concentration of the three life forms (shrub, tree, and conifer) all showed a decreasing trend under $\mathrm{N}$ addition in autumn. There are two possible reasons for this variation. One, is that these regulatory mechanisms may not be able to quantitatively supply sufficient $\mathrm{P}$ to balance the increase in $\mathrm{N}$ in plants under continuous $\mathrm{N}$ input [26]; however, the limited variations across seasons in soil TP, increased community $\mathrm{P}$ under ambient conditions and decreased $\mathrm{P}$ demand of leaves during this stage suggest that this explanation may not be viable. Another, more plausible reason, is internal nutrient retranslocation, i.e., the process by which plants transform nutrients in leaves into other tissues [29,49]. The recycling mechanism occurs not only in senescing leaves but also during the entire life cycle of leaves [54] as a response to N-induced $\mathrm{P}$ limitation. Plants thus transfer more P from mature green leaves, which have a relatively low $\mathrm{P}$ demand in autumn, to other tissues to support their growth. Unfortunately, we did not collect more data for nutrients in other tissues to support this explanation, and more research needs to be completed in the future. In the long term, the mitigating effect of $\mathrm{N}$ addition on $\mathrm{P}$ limitation may not be persistent, and the degree of $\mathrm{P}$ limitation will still be enhanced by $\mathrm{N}$ addition because of the reduced $\mathrm{P}$ concentration in leaves, which will slow the $\mathrm{P}$ recycling rate and further decrease the amount of available P $[12,47,55]$.

Mycorrhizal associations play a critical role in regulating the acquisition of limited nutrients [34,35]. Mycorrhizal associations exist in nearly all ecosystems, with mycorrhizal plants dominating in many habitats [56,57]. AM-associated plants are often dominant in low-latitude areas, whereas EM-associated plants are often dominant in high-latitude areas. Overall, compared to EM, AM associations result in more effective P acquisition [31,58]. Consistent with Deng et al. [16], who reported an increased AM:EM ratio in a young stand under $\mathrm{N}$ addition, we also found that the changed IV of AM species increased but that of EM species decreased with increasing $\mathrm{N}$ addition, which suggests once again an enhanced $\mathrm{P}$ limitation under $\mathrm{N}$ addition as well as the regulation of community N-induced P limitation. Furthermore, we did not observe significant differences in responses to $\mathrm{N}$ addition between shrubs and trees, but AM species and EM species did display such differences. Studies have shown that EM fungi tend to specialize in $\mathrm{N}$ acquisition, whereas $\mathrm{AM}$ species might experience secondary $\mathrm{N}$ limitation under the enhanced $\mathrm{P}$ limitation induced by $\mathrm{N}$ addition [20,59]. This may explain the diverse variation in $\mathrm{N}$ concentration under $\mathrm{N}$ addition between the two mycorrhizal types. Similar to the variation in community $\mathrm{P}$, the P concentration among EM species also decreased under $\mathrm{N}$ addition. Zhang et al. [33] found a significantly greater $\mathrm{P}$ resorption rate for EM-associated trees than for AM trees in a boreal forest, which may from another perspective bolster our explanation for the decrease in $\mathrm{P}$ during autumn. Moreover, the increased $\mathrm{P}$ level in AM species demonstrates a stronger capacity to acquire P. In addition, other properties are also important in driving the growth of a plant community, for example: The evolution of soil organic to humic matter, which may interact in the response of foliar N:P stoichiometry to $\mathrm{N}$ deposition $[60,61]$. 


\subsection{Status of Nutrient Limitation}

How to assess nutrient limitation in primary productivity is always a concern of ecologists, and a fertilization experiment is a frequently used method that defines nutrient limitation as a requirement for additional nutrients [26,47,62]. Accordingly, the improved foliar $\mathrm{N}$ level via $\mathrm{N}$ addition across the three seasons showed that $\mathrm{N}$ may be a constraint in this forest. Nevertheless, we cannot conclude that $\mathrm{N}$ is the sole limiting nutrient. In contrast, we infer that $\mathrm{P}$ is also a critical limiting nutrient for this forest because of the initiation of some adaptive strategies that aim to alleviate $\mathrm{P}$ limitation under $\mathrm{N}$ addition.

In addition to fertilization experiments, community foliar nutrient concentrations and ratios based on averages are widely applied for assessing nutrient limitation. Koerselman and Meuleman [27] found that a foliar N:P ratio $<14$ indicated that the plant was limited by $\mathrm{N}$ alone, that N:P $>16$ indicated limitation solely by $\mathrm{P}$, and that $14<\mathrm{N}: \mathrm{P}<16$ indicated colimitation. Later, Güsewell et al. [63] proposed a more conservative threshold value; i.e., $\mathrm{N}: \mathrm{P}<10$ and N:P $>20$ solely represented $\mathrm{N}$ limitation and $\mathrm{P}$ limitation, respectively. Recently, community N:P weighted by the $I V$ or biomass of species is also being applied in some research $[13,22]$. In this study, the values of $\mathrm{N}: \mathrm{P}$ across three seasons were all between 10 and 20, regardless of whether they were calculated using the weighted or average value. In addition, through a comparison with previous research during the peak season, our results show that the foliar $\mathrm{P}$ in the study region is lower than the worldwide average and that the foliar N:P is lower than the average for China. These results support the opinion of Han et al. [39], who found that foliar $\mathrm{P}$ across most areas in China was lower than the global average and that northern regions in China were more limited by N. More evidence regarding the existence of $\mathrm{P}$ limitation is reflected in the low-supplied soil AP. Through investigation of pools and distributions of soil P in China, Zhang et al. [64] found that dark brown forest soil, which is the zonal soil in this region, has a relatively high soil TP but a quite low soil AP compared to other soil types. The highest soil AP:TP ratio in this study was approximately 0.012 under ambient conditions. These results further prove our inference that $\mathrm{N}$ and $\mathrm{P}$ limitation coexist in this forest.

Studies have shown that the relative status of $\mathrm{N}$ vs. P limitation changes with succession [21,22]. Inputs of $\mathrm{N}$ and $\mathrm{P}$ have different sources; $\mathrm{P}$ is derived from rock weathering, whereas $\mathrm{N}$ can accumulate from the atmosphere through biological $\mathrm{N}$ fixation and atmospheric $\mathrm{N}$ deposition [65]. Therefore, young ecosystems lacking the input of atmospheric elements are usually limited by the supply of $\mathrm{N}$, and with the development of succession, $\mathrm{P}$ will decrease to a limiting level because of the accumulation of soil organic carbon and soil TN [26]. The old-growth temperate forest in the present study has a long history of succession, which may explain the reason for the observed $\mathrm{N}$ and $\mathrm{P}$ colimitation. Wang and Moore [30] also recently reported colimitation of $\mathrm{N}$ and $\mathrm{P}$ in an ombrotrophic peatland in eastern Ontario, Canada, and Goswami et al. [20] found evidence of P limitation in most middle-aged and mature stands in central New Hampshire, USA. These two regions are all at latitudes similar to that of the region in this study.

\section{Conclusions}

This is the first study that explores the divergent responses of foliar N:P stoichiometry during different seasons to $\mathrm{N}$ deposition. In this study, plant leaf stoichiometric characteristics showed different variations with seasonal changes, and responses to $\mathrm{N}$ deposition in three seasons also differed. Thus, significant variations in leaf stoichiometric characteristics across these three seasons over just four months may be worth considering. Our research emphasizes the importance of multiple sampling across seasons in a temperate forest. Broadleaved species vs. conifers and AM species vs. EM species showed significant differences in seasonal variation and in response to $\mathrm{N}$ addition. Arguing against the traditional consensus, the net primary productivity of this mixed broadleaved-Korean pine (Pinus koraiensis) forest, an old-growth temperate forest and a critical forest type in Northeast China, is under $\mathrm{N}$ and $\mathrm{P}$ colimitation. The level of $\mathrm{P}$ limitation is enhanced by $\mathrm{N}$ deposition, and this $\mathrm{N}$-induced 
P limitation may be alleviated by the adjustment of strategies for plant adaption such as nutrient retranslocation and mycorrhizal association.

Supplementary Materials: The following are available online at http:/ /www.mdpi.com/1999-4907/10/3/257/s1, Table S1: Marginal means of main factors.

Author Contributions: G.J. conceived and designed the experiments; D.Y. and H.M. performed the experiments; D.Y. analyzed the data; D.Y. contributed reagents/materials/analysis tools; D.Y. and G.J. wrote the paper.

Funding: This work was funded by Fundamental Research Funds for Central Universities (2572017EA02).

Acknowledgments: We thank three anonymous reviewers and editor for constructive suggestions to improve the quality of the manuscript.

Conflicts of Interest: The authors declare no conflict of interest.

\section{References}

1. Galloway, J.N.; Dentener, FJ.; Capone, D.G.; Boyer, E.W.; Howarth, R.W.; Seitzinger, S.P.; Asner, G.P.; Cleveland, C.C.; Green, P.A.; Holland, E.A.; et al. Nitrogen cycles: Past, present, and future. Biogeochemistry 2004, 70, 153-226. [CrossRef]

2. Neff, J.C.; Townsend, A.R.; Gleixner, G.; Lehman, S.J.; Turnbull, J.; Bowman, W.D. Variable effects of nitrogen additions on the stability and turnover of soil carbon. Nature 2002, 419, 915-917. [CrossRef] [PubMed]

3. Phoenix, G.K.; Emmett, B.A.; Britton, A.J.; Caporn, S.J.M.; Dise, N.B.; Helliwell, R.; Jones, L.; Leake, J.R.; Leith, I.D.; Sheppard, L.J.; et al. Impacts of atmospheric nitrogen deposition: Responses of multiple plant and soil parameters across contrasting ecosystems in long-term field experiments. Glob. Chang. Biol. 2012, 18, 1197-1215. [CrossRef]

4. Liu, X.; Duan, L.; Mo, J.; Du, E.; Shen, J.; Lu, X.; Zhang, Y.; Zhou, X.; He, C.; Zhang, F. Nitrogen deposition and its ecological impact in China: An overview. Environ. Pollut. 2011, 159, 2251-2264. [CrossRef] [PubMed]

5. Lu, X.; Mao, Q.; Gilliam, F.S.; Luo, Y.; Mo, J. Nitrogen deposition contributes to soil acidification in tropical ecosystems. Glob. Chang. Biol. 2014, 20, 3790-3801. [CrossRef] [PubMed]

6. Elser, J.J.; Bracken, M.E.; Cleland, E.E.; Gruner, D.S.; Harpole, W.S.; Hillebrand, H.; Ngai, J.T.; Seabloom, E.W.; Shurin, J.B.; Smith, J.E. Global analysis of nitrogen and phosphorus limitation of primary producers in freshwater, marine and terrestrial ecosystems. Ecol. Lett. 2007, 10, 1135-1142. [CrossRef] [PubMed]

7. Reich, P.B.; Oleksyn, J. Global patterns of plant leaf $\mathrm{N}$ and $\mathrm{P}$ in relation to temperature and latitude. Proc. Natl. Acad. Sci. USA 2004, 101, 11001-11006. [CrossRef] [PubMed]

8. Crowley, K.F.; McNeil, B.E.; Lovett, G.M.; Canham, C.D.; Driscoll, C.T.; Rustad, L.E.; Denny, E.; Hallett, R.A.; Arthur, M.A.; Boggs, J.L.; et al. Do nutrient limitation patterns shift from nitrogen toward phosphorus with increasing nitrogen deposition across the northeastern United States? Ecosystems 2012, 15, 940-957. [CrossRef]

9. Parfitt, R.L.; Ross, D.J.; Coomes, D.A.; Richardson, S.J; Smale, M.C.; Dahlgren, R.A. N and P in new zealand soil chronosequences and relationships with foliar $\mathrm{N}$ and P. Biogeochemistry 2005, 75, 305-328. [CrossRef]

10. Clark, C.M.; Tilman, D. Loss of plant species after chronic low-level nitrogen deposition to prairie grasslands. Nature 2008, 451, 712-715. [CrossRef] [PubMed]

11. Peñuelas, J.; Sardans, J.; Rivas-ubach, A.; Janssens, I.A. The human-induced imbalance between $\mathrm{C}, \mathrm{N}$ and $\mathrm{P}$ in earth's life system. Glob. Chang. Biol. 2012, 18, 3-6. [CrossRef]

12. Penuelas, J.; Poulter, B.; Sardans, J.; Ciais, P.; van der Velde, M.; Bopp, L.; Boucher, O.; Godderis, Y.; Hinsinger, P.; Llusia, J.; et al. Human-induced nitrogen-phosphorus imbalances alter natural and managed ecosystems across the globe. Nat. Commun. 2013, 4, 2934. [CrossRef] [PubMed]

13. Han, X.; Sistla, S.A.; Zhang, Y.H.; Lü, X.T.; Han, X.G. Hierarchical responses of plant stoichiometry to nitrogen deposition and mowing in a temperate steppe. Plant Soil 2014, 382, 175-187. [CrossRef]

14. Magill, A.H.; Aber, J.D.; Currie, W.S.; Nadelhoffer, K.J.; Martin, M.E.; McDowell, W.H.; Melillo, J.M.; Steudler, P. Ecosystem response to 15 years of chronic nitrogen additions at the Harvard forest LTER, Massachusetts, USA. For. Ecol. Manag. 2004, 196, 7-28. [CrossRef]

15. Mayor, J.R.; Wright, S.J.; Turner, B.L.; Austin, A. Species-specific responses of foliar nutrients to long-term nitrogen and phosphorus additions in a lowland tropical forest. J. Ecol. 2014, 102, 36-44. [CrossRef] 
16. Deng, M.; Liu, L.; Sun, Z.; Piao, S.; Ma, Y.; Chen, Y.; Wang, J.; Qiao, C.; Wang, X.; Li, P. Increased phosphate uptake but not resorption alleviates phosphorus deficiency induced by nitrogen deposition in temperate Larix principis-rupprechtii plantations. New Phytol. 2016, 212, 1019-1029. [CrossRef] [PubMed]

17. Aber, J.D.; Nadelhoffer, K.J.; Steudler, P.; Melillo, J.M. Nitrogen saturation in northern forest ecosystem. Bioscience 1989, 39, 378-386. [CrossRef]

18. Elser, J.J.; Fagan, W.F.; Kerkhoff, A.J.; Swenson, N.G.; Enquist, B.J. Biological stoichiometry of plant production: Metabolism, scaling and ecological response to global change. New Phytol. 2010, 186, 593-608. [CrossRef] [PubMed]

19. Ågren, G.I. Stoichiometry and nutrition of plant growth in natural communities. Annu. Rev. Ecol. Evol. Syst. 2008, 39, 153-170. [CrossRef]

20. Goswami, S.; Fisk, M.C.; Vadeboncoeur, M.A.; Garrison-Johnston, M.; Yanai, R.D.; Fahey, T.J. Phosphorus limitation of aboveground production in northern hardwood forests. Ecology 2018, 99, 438-449. [CrossRef]

21. Davidson, E.A.; de Carvalho, C.J.; Figueira, A.M.; Ishida, F.Y.; Ometto, J.P.; Nardoto, G.B.; Saba, R.T.; Hayashi, S.N.; Leal, E.C.; Vieira, I.C.; et al. Recuperation of nitrogen cycling in amazonian forests following agricultural abandonment. Nature 2007, 447, 995-998. [CrossRef]

22. Zhang, W.; Zhao, J.; Pan, F.; Li, D.; Chen, H.; Wang, K. Changes in nitrogen and phosphorus limitation during secondary succession in a karst region in southwest China. Plant Soil 2015, 391, 77-91. [CrossRef]

23. Chapin, F.S. The mineral nutrition of wild plants. Ann. Rev. Ecol. Syst. 1980, 11, 233-260. [CrossRef]

24. Chapin, F.S.; Vitousek, P.M.; Van Cleve, K. The nature of nutrient limitation in plant communities. Am. Nat. 1986, 127, 48-58. [CrossRef]

25. Vitousek, P.M.; Howarth, R.W. Nitrogen limitation on land and in the sea: How can it occur? Biogeochemistry 1991, 13, 87-115. [CrossRef]

26. Vitousek, P.M.; Porder, S.; Houlton, B.Z.; Chadwick, O.A. Terrestrial phosphorus limitation: Mechanisms, implications, and nitrogen-phosphorus interactions. Ecol. Appl. 2010, 20, 5-15. [CrossRef]

27. Koerselman, W.; Meuleman, A.F.M. The vegetation N:P ratio: A new tool to detect the nature of nutrient limitation. J. Appl. Ecol. 1996, 33, 1441-1450. [CrossRef]

28. Townsend, A.R.; Cleveland, C.C.; Asner, G.P.; Bustamamte, M.M.C. Controls over foliar N:P ratios in tropical forests. Ecology 2007, 88, 107-118. [CrossRef]

29. Fife, D.N.; Nambiar, E.K.S.; Saur, E. Retranslocation of foliar nutrients in evergreen tree species planted in a mediterranean environment. Tree Physiol. 2008, 28, 187-196. [CrossRef]

30. Wang, M.; Moore, T.R. Carbon, nitrogen, phosphorus, and potassium stoichiometry in an ombrotrophic peatland reflects plant functional type. Ecosystems 2014, 17, 673-684. [CrossRef]

31. Lambers, H.; Raven, J.A.; Shaver, G.R.; Smith, S.E. Plant nutrient-acquisition strategies change with soil age. Trends Ecol. Evol. 2008, 23, 95-103. [CrossRef]

32. Jeffries, P.; Gianinazzi, S.; Perotto, S.; Turnau, K.; Barea, J.M. The contribution of arbuscular mycorrhizal fungi in sustainable maintenance of plant health and soil fertility. Biol. Fertil. Soils 2003, 37, 1-16.

33. Zhang, H.Y.; Lu, X.T.; Hartmann, H.; Keller, A.; Han, X.G.; Trumbore, S.; Phillips, R.P. Foliar nutrient resorption differs between arbuscular mycorrhizal and ectomycorrhizal trees at local and global scales. Glob. Ecol. Biogeogr. 2018, 27, 875-885. [CrossRef]

34. Smith, S.E.; Smith, F.A. Roles of arbuscular mycorrhizas in plant nutrition and growth: New paradigms from cellular to ecosystem scales. Annu. Rev. Plant Biol. 2011, 62, 227-250. [CrossRef]

35. Van der Heijden, M.G.; Martin, F.M.; Selosse, M.A.; Sanders, I.R. Mycorrhizal ecology and evolution: The past, the present, and the future. New Phytol. 2015, 205, 1406-1423. [CrossRef]

36. Read, D.J.; Perez-Moreno, J. Mycorrhizas and nutrient cycling in ecosystems-A journey towards relevance? New Phytol. 2003, 157, 475-492. [CrossRef]

37. Shi, W.; Wang, Z.Q.; Liu, J.L.; Gu, J.C.; Guo, D.L. Fine root morphology of twenty hardwood species in maoershan natural secondary forest northeastern China. J. Plant Ecol. 2008, 32, 1217-1226.

38. Elser, J.J.; Sterner, R.W.; Gorokhova, E.; Fagan, W.F.; Markow, T.A.; Cotner, J.B.; Harrison, J.F.; Hobbie, S.E.; Odell, G.M.; Weider, L.J. Biological stoichiometry from genes to ecosystems. Ecol. Lett. 2000, 3, 540-550. [CrossRef]

39. Han, W.; Fang, J.; Guo, D.; Zhang, Y. Leaf nitrogen and phosphorus stoichiometry across 753 terrestrial plant species in China. New Phytol. 2005, 168, 377-385. [CrossRef] 
40. Sterner, R.W.; Elser, J.J. Ecological Stoichiometry: The Biology of Elements from Molecules to the Biosphere; Princeton University Press: Princeton, NJ, USA, 2002.

41. Aronsson, A.; Elowson, S.; Persson, T. Effects of irrigation and fertilization on mineral nutrients in scots pine needles. Ecol. Bull. 1980, 32, 219-228.

42. Son, Y.; Lee, I.K.; Ryu, S.R. Nitrogen and phosphorus dynamics in foliage and twig of pitch pine and Japanese larch plantations in relation to fertilization. J. Plant Nutr. 2000, 23, 697-710. [CrossRef]

43. Güsewell, S. N:P ratios in terrestrial plants: Variation and functional significance. New Phytol. 2004, 164, $243-266$. [CrossRef]

44. Reich, P.B.; Uhl, C.; Walters, M.B.; Ellsworth, D.S. Leaf lifespan as a determinant of leaf structure and function among 23 amazonian tree species. Oecologia 1991, 86, 16-24. [CrossRef]

45. Reich, P.B.; Walters, M.B.; Ellsworth, D.S. From tropics to tundra: Global convergence in plant functioning. Proc. Natl. Acad. Sci. USA 1997, 94, 13730-13734. [CrossRef]

46. Westoby, M.; Falster, D.S.; Moles, A.T.; Vesk, P.A.; Wright, I.J. Plant ecological strategies: Some leading dimensions of variation between species. Annu. Rev. Ecol. Syst. 2002, 33, 125-159. [CrossRef]

47. Li, Y.; Niu, S.; Yu, G. Aggravated phosphorus limitation on biomass production under increasing nitrogen loading: A meta-analysis. Glob. Chang. Biol. 2016, 22, 934-943. [CrossRef]

48. Perring, M.P.; Hedin, L.O.; Levin, S.A.; McGroddy, M.; de Mazancourt, C. Increased plant growth from nitrogen addition should conserve phosphorus in terrestrial ecosystems. Proc. Natl. Acad. Sci. USA 2008, 105, 1971-1976. [CrossRef]

49. Cleveland, C.C.; Houlton, B.Z.; Smith, W.K.; Marklein, A.R.; Reed, S.C.; Parton, W.; Del Grosso, S.J.; Running, S.W. Patterns of new versus recycled primary production in the terrestrial biosphere. Proc. Natl. Acad. Sci. USA 2013, 110, 12733-12737. [CrossRef]

50. Phoenix, G.K.; Booth, R.E.; Leake, J.R.; Read, D.J.; Grime, J.P.; Lee, J.A. Simulated pollutant nitrogen deposition increases $\mathrm{P}$ demand and enhances root-surface phosphatase activities of three plant functional types in a calcareous grassland. New Phytol. 2003, 161, 279-290. [CrossRef]

51. Treseder, K.K. A meta-analysis of mycorrhizal responses to nitrogen, phosphorus, and atmospheric $\mathrm{CO}_{2}$ in field studies. New Phytol. 2004, 164, 347-355. [CrossRef]

52. Long, M.; Wu, H.H.; Smith, M.D.; La Pierre, K.J.; Lü, X.T.; Zhang, H.Y.; Han, X.G.; Yu, Q. Nitrogen deposition promotes phosphorus uptake of plants in a semi-arid temperate grassland. Plant Soil 2016, 408, 475-484. [CrossRef]

53. Yu, Q.; Chen, Q.; Elser, J.J.; He, N.; Wu, H.; Zhang, G.; Wu, J.; Bai, Y.; Han, X. Linking stoichiometric homoeostasis with ecosystem structure, functioning and stability. Ecol. Lett. 2010, 13, 1390-1399. [CrossRef] [PubMed]

54. Nambiar, E.K.S.; Fife, D.N. Nutrient retranslocation in temperate conifers. Tree Physiol. 1991, 9, $185-207$. [CrossRef]

55. Knorr, M.; Frey, S.D.; Curtis, P.S. Nitrogen additions and litter decomposition: A meta-analysis. Ecology 2005, 86, 3252-3257. [CrossRef]

56. Brundrett, M.C. Mycorrhizal associations and other means of nutrition of vascular plants: Understanding the global diversity of host plants by resolving conflicting information and developing reliable means of diagnosis. Plant Soil 2009, 320, 37-77. [CrossRef]

57. Read, D.J.; Lewis, D.H.; Fitter, A.H.; Alexander, I.J.; Battley, E.H. Mycorrhizas in ecosystems. Experientia 1991, 47, 376-391. [CrossRef]

58. Averill, C.; Turner, B.L.; Finzi, A.C. Mycorrhiza-mediated competition between plants and decomposers drives soil carbon storage. Nature 2014, 505, 543-545. [CrossRef]

59. Smith, S.; Read, D. Mycorrhizal symbiosis. Q. Rev. Biol. 2008, 3, $273-281$.

60. Pizzeghello, D.; Nicolini, G.; Nardi, S. Hormone-like activity of humic substances in Fagus sylvaticae forests. New Phytol. 2001, 151, 647-657. [CrossRef]

61. Pizzeghello, D.; Nicolini, G.; Nardi, S. Hormone-like activities of humic substances in different forest ecosystems. New Phytol. 2002, 155, 393-402. [CrossRef]

62. Gilbert, J.B.; Lawesj, H. Agricultural, botanical, and chemical results of experiments on the mixed herbage of permanent meadow, conducted for more than twenty years in succession on the same land. Part I. Philos. Trans. R. Soc. Lond. 1880, 171, 289-416. 
63. Güsewell, S.; Koerselman, W.; Verhoeven, J.T.A. Biomass N:P ratios as indicators of nutrient limitation for plant populations in wetland. Ecol. Appl. 2003, 13, 372-384. [CrossRef]

64. Zhang, C.; Tian, H.Q.; Liu, J.Y.; Wang, S.Q.; Liu, M.L.; Pan, S.F.; Shi, X.Z. Pools and distributions of soil phosphorus in China. Glob. Biogeochem. Cycles 2005, 19. [CrossRef]

65. Walker, T.W.; Syers, J.K. The fate of phosphorus during pedogenesis. Geoderma 1976, 15, 1-19. [CrossRef]

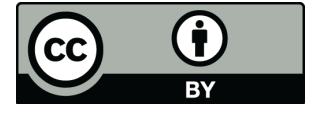

(C) 2019 by the authors. Licensee MDPI, Basel, Switzerland. This article is an open access article distributed under the terms and conditions of the Creative Commons Attribution (CC BY) license (http:/ / creativecommons.org/licenses/by/4.0/). 